\title{
Detection of Urinary Tract Infection (UTI) among pregnant women in Oluyoro Catholic Hospital, Ibadan, South-Western Nigeria
}

\author{
Okonko, I. O., ${ }^{1 \star}$ ljandipe, L. A., ${ }^{2}$ Ilusanya, A. O., ${ }^{2}$ Donbraye-Emmanuel, O. B., ${ }^{3}$ Ejembi, J., ${ }^{4}$ Udeze A. O., ${ }^{5}$ \\ Egun O. C., ${ }^{6}$ Fowotade A. ${ }^{7}$ and Nkang A. O. ${ }^{1}$ \\ ${ }^{1}$ Department of Virology, Faculty of Basic Medical Sciences, College of Medicine, University of Ibadan, University \\ College Hospital (UCH) Ibadan, Nigeria. \\ ${ }^{2}$ Department of Microbiology, Olabisi Onabanjo University, Ago-Iwoye, Ogun State, Nigeria. \\ ${ }^{3}$ Department of Medical Microbiology and Parasitology, University College Hospital (UCH), Ibadan, Nigeria. \\ ${ }^{4}$ Department of Clinical Microbiology, Ahmadu Bello University Teaching Hospital (ABUTH), Zaria, Kaduna State, Nigeria. \\ ${ }^{5}$ Virology Unit, Department of Microbiology, Faculty of Sciences, University of Ilorin, llorin, Nigeria. \\ ${ }^{6}$ Department of Biochemistry, Faculty of Basic Medical Sciences, College of Medicine, University of Ibadan, Ibadan, \\ Nigeria. \\ ${ }^{7}$ Department of Medical Microbiology and Parasitology, University of Ilorin Teaching Hospital, Ilorin, Kwara State, \\ Nigeria. \\ E-mail:mac2finney@yahoo.com
}

Received 2 January 2009; received in revised form 3 July 2009; accepted 7 July 2009

\begin{abstract}
This study reports the detection of urinary tract infections among 80 pregnant women in Oluyoro Catholic Hospital Ibadan, South-Western, Nigeria for a period of 6 months. It was carried out to detect the presence of urinary tract infection in pregnant women, and to isolate and to identify the pathogens responsible for the infection. A total of 80 clean voided mid-stream urine samples were collected from pregnant women between the ages of 21-40 years. The results showed 38 bacterial isolates with an incidence of $47.5 \%$ in this population. The isolates were identified based on colonial morphology, microscopic characteristics, and biochemical tests using Bergey's Manual of Determinative Bacteriology. Escherichia coli 16(42.1\%) was the most predominant organism. This was followed by Staphylococcus aureus $11(28.9 \%)$, Klebsiella aerogenes $7(18.4 \%)$, Pseudomonas aeruginosa 2(5.3\%), and a mixed culture of Klebisella aerogenes and Staphylococcus aureus 2(5.3\%). Urine microscopy revealed the presence of Pus cells in the urine samples collected. Two samples, representing $2.5 \%$ of the samples contained yeast cells, suggesting that Candidiasis was also predominant. The high incidence rate of $47.5 \%$ reported in this study should be of great concern, as not only do UTIs pose a threat to health, but they also impose an economic and social burden due to the stigma associated with these infections.
\end{abstract}

Keywords: bacteriuria, pregnant women, urine, Urinary Tract Infection

\section{INTRODUCTION}

Urinary Tract Infections (UTIs) is an infection caused by the presence and growth of microorganism anywhere in the urinary tract and is perhaps the single commonest bacterial infection of mankind (Morgan and McKenzie, 1993; Ebie et al., 2001). Urinary tract includes the organs that collect and store urine and release it from the body which include: kidneys, ureters, bladder and urethra. UTIs are among the most common bacterial infections in humans, both in the community and hospital settings and have been reported in all age groups in both sexes (Hooton et al., 1995). It is a serious health problem affecting millions of people each year and the leading cause of Gram-negative bacteriaemia. UTIs are also the leading cause of morbidity and health care expenditures in persons of all ages. In the United States, it is estimated from surveys of office practices, hospital-based clinics and emergency departments that these infections account for over eight million cases of UTI annually and more than 1 million hospitalizations, for an overall annual cost in excess of $\$ 1$ billion (Patton et al., 1991; Kunin, 1994; Aiyegoro et al., 2007). The pathogens producing UTI have been said to be mostly derived from the hospital (Tapsal et al., 1975; Ebie et al., 2001).

UTI has become the most common hospital-acquired infection, accounting for as many as $35 \%$ of nosocomial infections, and it is the second most common cause of bacteraemia in hospitalized patients (Weinstein et al., 1997; Stamm, 2002; Kolawole et al., 2009). UTI accounts for a significant part of the work load in clinical microbiology laboratories and enteric bacteria (in particular, Escherichia coli) remain the most frequent cause of UTI, although the distribution of pathogens that 
cause UTI is changing (Ojiegbe and Nworie, 2000; Kolawole et al., 2009).

Numerous reports have also suggested that UTI can occur in both males and females of any age, with bacterial counts as low as 100 colony forming units (CFU) per millimeter in urine (Akinyemi et al., 1997; Ebie et al., 2001). This is common in patients with symptoms of acute urethral syndrome, males with chronic prostatitis and patients with indwelling catheters (Karen et al., 1994). Females are however believed to be more affected than males except at the extremes of life (Ebie et al., 2001; Kolawole et al., 2009). Untreated upper UTI in pregnancy carries well documented risks of morbidity, and rarely, mortality to the pregnant women (NICE 2003). Sexually active young women are disproportionately affected. An estimated 40 percent of women report having had a UTI at some point in their lives (Kunin, 1994).

Recently published studies have added to the body of knowledge concerning the pathogenesis, diagnosis and management of UTls (Orenstein and Wong, 1999). Usually, a UTI is caused by bacteria that can also live in the digestive tract, in the vagina, or around the urethra, which is at the entrance to the urinary tract. Most often these bacteria enter the urethra and travel to the bladder and kidneys. Usually, the body removes the bacteria, and shows no symptoms. The signs and symptoms include burning feeling during urination, frequent or intense urges to urinate, even when one passes little urine, backaches or pains at the lower abdomen, cloudy, dark, bloody, or unusual-smelling urine, fever or chills (NKUDIC, 2005).

Women tend to have UTIs more often than men because bacteria can reach the bladder more easily in women. This is partially due to the short and wider female urethra and its proximity to anus. Bacteria from the rectum can easily travel up the urethra and cause infections (Ebie et al., 2001; Kolawole et al., 2009). Moreover, the main factors predisposing married women to bacteriuria are pregnancy and sexual intercourse $(\mathrm{NIH}, 2004)$. Sexual activity increases the chances of bacterial contamination of female urethra. Sexual intercourse may also cause bacteria to be pushed into the urethra. This anatomical relationship of the female urethra to the vagina makes it liable to trauma during sexual intercourse as well as bacteria being massaged up the urethra into the bladder during pregnancy/ child birth (Duerden et al., 1990; Ebie et al., 2001, Kolawole et al., 2009). Using a diaphragm can also lead to UTIs because diaphragms push against the urethra and make it harder to completely empty the bladder. The urine that stays in the bladder is more likely to grow bacteria and cause infections (APFP, 2004; NKUDIC, 2005).

However, the importance of coliform bacilli in UTI among pregnant women has long been known in developed countries (Omar and ElHaj, 1992). Health care practitioners regularly have to make decisions about prescription of antibiotics for urinary tract infections. UTI is the second most common clinical indication for empirical antimicrobial treatment in primary and secondary care, and urine samples constitute the largest single category of specimens examined in most medical microbiology laboratories (Morgan and McKenzie, 1993).

UTI is challenging, not only because of the large number of infections that occur each year, but also because the diagnosis of UTI is not always straight forward (Kolawole et al., 2009). Criteria for the diagnosis of UTI vary greatly depending on the patients and context. According to Tena et al. (2008), there is not 1 best way of performing urine cultures. Guidelines for the diagnosis of UTI includes the use of sheep blood agar and either MacConkey agar or a similar selective medium for routine urine culture. The plates should be incubated overnight (at least 16 hours) at $37^{\circ} \mathrm{C}$ in ambient air; alternatively, the blood agar plate can be incubated in elevated $(3 \%-8 \%)$ $\mathrm{CO}_{2}$ (Clarridge et al., 1988). For fastidious microorganisms, chocolate agar can be added to the MacConkey agar and the plates incubated in $5 \% \mathrm{CO}_{2}$ for 2 days (Clarridge et al., 1988). $\mathrm{CO}_{2}$ can play a role in the growth of microorganisms for instance, $E$. coli as a substrate for carboxylation reactions (Kozliak et al., 1995). There is considerable evidence of practice variation in use of diagnostic tests, interpretation of signs or symptoms and initiation of antibiotic treatment such as drug selection, dose, duration and route of administration (Jamieson et al., 2006). For patients with symptoms of UTI and bacteriuria the main aim of treatment is to get rid of infectious bacteria causing the symptoms. Secondary outcomes are adverse effects of treatment or recurrence of symptoms. This study therefore focuses on the detection and incidence of UTI among pregnant women Ibadan, South-Western, Nigeria. It also aimed to isolate and identify the organisms isolated from clinical specimen.

\section{MATERIALS AND METHODS}

\section{Study population}

Urine samples were collected from a total of 80 pregnant women between the ages of 21 to 40 years. All these persons were outpatients attending the antenatal clinics in Oluyoro Catholic Hospital $(\mathrm{OCH})$ Ibadan, Oyo state. The urine samples were obtained by informed consent of the pregnant women used for this study and the permission to that effect was obtained from the ethical committee of the hospitals.

\section{Urine collection}

Clean catch urine samples were collected in sterile universal containers as described by Karlowsky et al. (2006) and Solberg et al. (2006). Eighty "clean catch" midstream urine (MSU) samples were collected inside sterile disposable universal bottles from pregnant women. They were instructed on how to collect samples and the need for prompt delivery to the laboratory. The samples were labeled and transported to the Medical Microbiology and Parasitology laboratory of University College Hospital (UCH), Ibadan in iced pack and were analyzed within 30 minutes to 1 hour of collection. 


\section{Demographic and clinical information}

Demographic and clinical information of the subjects were obtained by chart abstraction and recorded on a prepared data collection form. The study groups were also stratified by Age distribution. Information was collected on the women's age, occupation, menstrual and obstetric histories, gestational age, and parity, perceived gynaecological symptoms, health care-seeking behaviour and contraceptive practices.

\section{Sterilization of media and materials}

The media used were Nutrient Agar (NA) from Biotec Limited, while Nutrient Broth (NB), MacConkey agar (MCA), Blood Agar (BA) and Cystein Lactose Eletrolyte Deficient (CLED) Agar were supplied by Oxoid Limited. All glassware were washed with detergent and rinsed with water, then allowed to dry. The glassware were later wrapped in aluminum foil and sterilized in a hot air oven at $160{ }^{\circ} \mathrm{C}$ for $3 \mathrm{~h}$. Media were prepared according to the manufacturer's specifications and sterilized by autoclaving at $121 \mathrm{lb} / \mathrm{g}$ for $15 \mathrm{~min}$.

\section{Microscopy}

The urine samples were mixed and aliquots centrifuged at $5000 \mathrm{rpm}$ for $5 \mathrm{~min}$. The deposits were examined using both 10X and 40X objectives. Samples with 10 white blood cells $/ \mathrm{mm}^{3}$ were regarded as pyuric (Smith et al., 2003). A volume of the urine samples were applied to a glass microscope slide, allowed to air dry, stained with gram stain, and examined microscopically (Kolawole et al., 2009).

\section{Culturing of urine sample}

This was carried out as described by Cheesbrough (2002, 2004) and Prescott et al. (2008). Ten-fold serial dilutions were made by transferring $1.0 \mathrm{~mL}$ of the sample in $9.0 \mathrm{~mL}$ of sterile physiological saline. One $\mathrm{mL}$ was then poured into molten nutrient agar in Petri dishes and rotated gently for proper homogenization. The contents were allowed to set and the plates were then incubated at $37^{\circ} \mathrm{C}$ for $24 \mathrm{~h}$. Bacterial colonies appearing on the plates after the incubation period were enumerated to determine urine samples with significant bacteriuria. A loopful of each urine sample was also streaked on Mac Conkey agar and Blood agar plate for the isolation of the bacteria present in the urine. After incubation, plates with growth were selected, the colonies were isolated using inoculating loop and subsequently subcultured on agar slants for use in further tests.

\section{Identification of isolates}

The methods used in the identification and characterization of isolated bacteria include Gram stain followed by microscopic examination, motility test and biochemical tests according to Cheesbrough (2002;
2004). The isolates were identified by Bergey's Manual for Determinative Bacteriology (Buchanan and Gribbons, 1974).

\section{RESULTS}

Of the 80 samples examined in this study, only fifteen samples were observed to have pus cells, 4 had Schistosoma haematobium and yeast cells (Table 1 ).

Table 1: Microscopic examination of urine samples

\begin{tabular}{lc}
\hline \multicolumn{1}{c}{ Isolates } & $\begin{array}{c}\text { No. of Positive } \\
\text { Samples (\%) }\end{array}$ \\
\hline Pus cells & $15(62.5)$ \\
Schistosoma haematobium & $4(16.7)$ \\
Yeast cells & $4(16.7)$ \\
\hline Total & $\mathbf{2 4 ( 3 0 . 0 )}$ \\
\hline
\end{tabular}

Also, of the 80 samples examined in this study, 38 $(47.5 \%)$ were found to contain heavy and appreciable bacterial growth (significant bacteriuria) while 42 (52.5\%) had no appreciable bacterial growth (Table 2). Urine microscopy revealed Pus cells in the urine samples collected while yeast cells was only found in $2(2.5 \%)$ of the samples. Culture plates with bacteria counts greater than or equal to $1 \times 10^{5} \mathrm{cfu} / \mathrm{mL}$ were taken as positive, thus indicative of UTI. The bacteria isolates were identified based on colony morphology characteristics, Gram stain reaction and biochemical tests.

Table 2 shows the incidence of UTI in relation to age of the subjects. Table 1 shows the incidence of UTI in relation to age of the subjects. It shows a high percentage of organisms were isolated from pregnant women within the ages 21-25 years, 31-35 years and 36-40 years while age groups $26-30$ years had the least percentage (37.1\%) as shown in Table 1.

Table 2: Distribution of UTI in relation to age of pregnant women

\begin{tabular}{cccc}
\hline $\begin{array}{c}\text { Age } \\
\text { Group } \\
\text { (years) }\end{array}$ & $\begin{array}{c}\text { No. } \\
\text { Tested } \\
(\%)\end{array}$ & $\begin{array}{c}\text { No. } \\
\text { Positive } \\
(\%)\end{array}$ & $\begin{array}{c}\text { No. Negative } \\
(\%)\end{array}$ \\
\hline $21-25$ & $14(17.5)$ & $7(50.0)$ & $7(50.0)$ \\
$26-30$ & $35(43.8)$ & $13(37.1)$ & $22(62.9)$ \\
$31-35$ & $22(27.5)$ & $11(50.0)$ & $11(50.0)$ \\
$36-40$ & $9(11.3)$ & $7(77.8)$ & $2(22.2)$ \\
\hline Total & $\mathbf{8 0 ( 1 0 0 . 0 )}$ & $\mathbf{3 8 ( 4 7 . 5 )}$ & $\mathbf{4 2 ( 5 2 . 5 )}$ \\
\hline
\end{tabular}

Of the 38 isolates obtained, Gram-negative bacteria occurred more frequently than Gram-positive bacteria, constituting $25(65.8 \%)$ of the total isolates. These include Escherichia coli 16 (42.1\%), Klebsiella aerogenes 7 (18.4\%) and Pseudomonas aeruginosa 2 (5.3\%) as shown in Table 3. Gram-positive bacteria accounted for $11(28.9 \%)$, with Staphylococcus aureus 11 (28.9\%) and mixed cultures of Klebsiella spp. and Staphylococcus spp. accounting for $2(5.3 \%)$ as shown in Table 3 . It was also 
found that the rate of isolation of Klebsiella aerogenes and Staphylococcus aureus was higher in specimens collected from pregnant women in all age brackets while Pseudomonas aeruginosa were isolated exclusively from age brackets $36-40$ years.

Table 3: Frequency of isolation of organisms in pregnant women

\begin{tabular}{ll}
\hline \multicolumn{1}{c}{ Isolates } & \multicolumn{1}{c}{ No. of Positive Samples } \\
& \multicolumn{1}{c}{$(\%)$} \\
\hline Escherichia coli & $16(42.1)$ \\
Staphylococcus aureus & $11(28.9)$ \\
Klebsiella aerogenes & $7(18.4)$ \\
Pseudomonas aeruginosa & $2(5.3)$ \\
Mixed cultures: Klebsiella \& & $2(5.3)$ \\
Staphylococcus spp. & \\
\hline Total & $\mathbf{3 8 ( 1 0 0 . 0 )}$ \\
\hline
\end{tabular}

Table 4 shows the incidence of UTI by occupational group. UTIs were more prevalent among civil servants, this constituted $77.8 \%$ of the pregnant women with UTI, followed by teachers (70\%), businesswomen (53.8\%), traders $(40.0 \%)$, professionals/artisans/full housewives (36.4\%), and students $30.4 \%$ (Table 3).

Table 4: Incidence by occupational groups

\begin{tabular}{lcc}
\hline $\begin{array}{c}\text { Occupational } \\
\text { Groups }\end{array}$ & No. Tested & No. Positive (\%) \\
\hline Students & 23 & $7(30.4)$ \\
Teachers & 10 & $7(70.0)$ \\
Civil Servants & 9 & $7(77.8)$ \\
Businesswomen & 13 & $7(53.8)$ \\
Traders & 15 & $6(40.0)$ \\
Professionals/Artis & 11 & $4(36.4)$ \\
ans/Housewives & & \\
\hline Total & $\mathbf{8 0}$ & $\mathbf{3 8 ( 4 7 . 5 )}$ \\
\hline
\end{tabular}

Distribution of UTI in relation to parity (No. of pregnancy) is shown in Table 5. Fourteen (58.3\%) of 24 women who were in their $3^{\text {rd }}$ pregnancy and above or who have had more than 3 children had UTIs, 7 (43.7\%) of 16 women were in their $2^{\text {nd }}$ pregnancy also had UTIs while 17 $(42.5 \%)$ of the 40 women who were in their $1^{\text {st }}$ pregnancy had UTIs as shown in Table 5 . This showed that parity is one of the possible factors affecting the prevalence UTIs among women.

Table 5: Incidence of UTI by parity (no. of pregnancy)

\begin{tabular}{lll}
\hline \multicolumn{1}{c}{ Parity } & \multicolumn{1}{c}{ No. Tested } & No. Positive (\%) \\
\hline First pregnancy & 40 & $17(42.5)$ \\
$2^{\text {nd }}$ pregnancy & 16 & $7(43.7)$ \\
$3^{\text {rd }}$ pregnancy & 24 & $14(58.3)$ \\
and above & & \\
\hline Total & $\mathbf{8 0}$ & $\mathbf{3 8 ( 4 7 . 5 )}$ \\
\hline
\end{tabular}

Table 6 shows the incidence of UTI by gestational age (age of pregnancy) as at the time of this study. This revealed that women in their 6th and 7th month of their pregnancy had the higher incidences of UTI; $50.0 \%$ and $71.4 \%$ respectively while women in the early month of their pregnancy had no specific bacteria growth and shows no sign of UTIs.

Table 6: Incidence of UTI by gestational age (age of pregnancy)

\begin{tabular}{ccc}
\hline $\begin{array}{c}\text { Age of } \\
\text { Pregnancy } \\
\text { (Months) }\end{array}$ & No. Tested (\%) & No. Positive (\%) \\
\hline 3 & 2 & Nil \\
4 & 4 & $2(50.0)$ \\
5 & 11 & $3(27.3)$ \\
6 & 14 & $7(50.0)$ \\
7 & 14 & $10(71.4)$ \\
8 & 24 & $12(45.8)$ \\
9 & 11 & $5(45.5)$ \\
\hline Total & $\mathbf{8 0}$ & $\mathbf{3 8 ( 4 7 . 5 )}$ \\
\hline
\end{tabular}

Table 7 shows the incidence of UTI by trimester (a period of three months, especially one of the three threemonth periods into which human pregnancy is divided for medical purposes) as at the time of this study. This revealed that women in their $3^{\text {rd }}$ trimester of their pregnancy had the highest incidence of UTI [27(55.1\%)], followed by women in their $2^{\text {nd }}$ trimester [12(41.4\%)] while women in their first trimester of their pregnancy, though fewer in number, had no specific bacteria growth and shows no sign of UTIs.

Table 7: Incidence of UTI by trimester (period of 3 threemonths of pregnancy)

\begin{tabular}{lcc}
\hline $\begin{array}{l}\text { Trimester (period of } \\
\mathbf{3} \text { three-months) }\end{array}$ & $\begin{array}{c}\text { No. Tested } \\
(\%)\end{array}$ & $\begin{array}{c}\text { No. Positive } \\
(\%)\end{array}$ \\
\hline $\begin{array}{l}\text { First trimester }\left(1^{\text {st }} 3\right. \\
\text { months) }\end{array}$ & 02 & Nil \\
$\begin{array}{l}\text { Second trimester }\left(2^{\text {nd }}\right. \\
\begin{array}{l}\text { months) } \\
\text { Third trimester }\left(3^{\text {rd }} 3\right.\end{array}\end{array}$ & 29 & $12(41.4)$ \\
months) & 49 & $27(55.1)$ \\
\hline Total & $\mathbf{8 0}$ & $\mathbf{3 8 ( 4 7 . 5 )}$ \\
\hline
\end{tabular}

Table 8 shows the incidence of UTI in relation to the presenting clinical history. Among all pregnant women in the study, 38 (47.5) reported with symptom suggestive of an $\mathrm{UTI}$ and reproductive tract infection (RTI), including white discharge $(42.5 \%)$, burning sensation while passing urine $(1.3 \%)$ and vaginal itch $(8.8 \%)$, others include abdominal pains $(40 \%)$, malaria $(8.8 \%)$, vomiting/spitting $(5.0 \%)$ etc. Among those $48(60 \%)$ women reported with symptoms, 17 (35.4\%) women had one symptom, 33 $(68.8 \%)$ women had two symptoms and 13 (27.1) women had all the three. Only $35(72.9 \%)$ of the 48 pregnant women who showed symptoms of UTIs had specific 
Table 8: Incidence of UTI by clinical history

\begin{tabular}{lccc}
\hline \multicolumn{1}{c}{ Clinical History } & No. Tested (\%) & No. Positive (\%) & No. Negative (\%) \\
\hline Symptomatic & $48(60.0)$ & $35(72.9)$ & $13(27.1)$ \\
No Symptoms & $5(6.3)$ & $3(60.0)$ & $2(40.0)$ \\
Discharges & $34(42.5)$ & $13(38.2)$ & $21(61.8)$ \\
Burning Sensations & $1(1.3)$ & $1(100.0)$ & Nil \\
Abdominal Pains & $32(40.0)$ & $18(56.3)$ & $3(75.0)$ \\
Swollen Legs & $4(5.0)$ & $1(25.0)$ & $12(54.5)$ \\
Backache & $22(27.5)$ & $10(45.5)$ & $1(14.3)$ \\
Malaria & $7(8.8)$ & $6(85.7)$ & $5(55.6)$ \\
Headache & $9(11.3)$ & $4(44.4)$ & Nil \\
Stomachache & $1(1.3)$ & $1(100.0)$ & $3(50.0)$ \\
Waist pain & $6(7.5)$ & $3(50.0)$ & Nil \\
Cough & $1(1.3)$ & $1(100.0)$ & Nil \\
Dizzy & $1(1.3)$ & $1(100.0)$ & $4(100.0)$ \\
Vomiting/Spitting & $4(5.0)$ & $1(100.0)$ & Nil \\
Muscle pull & $1(1.3)$ & $3(100.0)$ & Nil \\
Body pain & $3(3.8)$ & $1(100.0)$ & Nil \\
Hand pain & $1(1.3)$ & $2(50.0)$ & $2(50.0)$ \\
Leg/Knee pain & $4(5.0)$ & $1(50.0)$ & $1(50.0)$ \\
Thing pain & $2(2.5)$ & $\mathrm{Nil}$ & $1(100.0)$ \\
Shoulder pain & $1(1.3)$ & $\mathrm{Nil}$ & $1(100.0)$ \\
Side pain & $1(1.3)$ & $\mathrm{Nil}$ & $1(100.0)$ \\
Buttocks pain & $1(1.3)$ & $1(100.0)$ & $\mathrm{Nil}$ \\
Cold & $1(1.3)$ & $1(100.0)$ & Nil \\
Sleeplessness & $1(1.3)$ & $3(42.9)$ & $4(57.1)$ \\
ltchy Sensation & $7(8.8)$ & & \\
\hline
\end{tabular}

growth in the urine culture while $3(60.0 \%)$ of the 5 pregnant women which had no symptoms of UTI gave positive urine cultures (Table 7).

\section{DISCUSSION}

The incidence of UTIs in this study population was $47.5 \%$. This is similar to the figures reported in previous studies. This study is in agreement with other reports which stress that UTI is more frequent in females than in males, during youth and adulthood (Ibeawuchi and Mbata, 2002; Asinobi et al., 2003; Olaitan, 2006; Mbata, 2007). The finding of this study is higher than the incidence rate of $11.9 \%$ reported by Aiyegoro et al. (2007) among children and adolescents in lle-lfe and $16.5 \%$ reported by Okafor et al. (1993) in patients between ages 0 and 20 years. This figure is also higher than the prevalence rate of $22 \%$ significant bacteriuria reported by Ekweozor and Onyemenen (1996) in Ibadan and $25.6 \%$ by Nedolisa (1998) at the Jos University Teaching Hospital (JUTH). The findings of this study is also higher than the incidence rate of $28.1 \%$ reported by Olowu (1996) in a population of 2780 out-patients at the Lagos University Teaching Hospital (LUTH) and a prevalence rate of $30 \%$ reported by Anochie et al. (2001) among a population of 100 school children, between ages $4-18$ years in a rural community in Enugu as well as $38.6 \%$ reported by Akinyemi et al. (1997) in Lagos, Nigeria and 35.5\% rate recorded by Ebie et al. (2001) in Rukuba Military Cantoment, Jos, Plateau State.

However, the findings in this study comparably to the $58 \%$ incidence rate of UTI reported by Onifade et al. (2005) in a similar study among pregnant women in Ondo state, but lower than a prevalence rate of $71.6 \%$ earlier reported in a similar study by Jellheden et al. (1996) in non-pregnant women less than 50 years of age with acute systems of UTIs and with Mbata (2007) who recorded $77.9 \%$ among Prison inmates in Nigeria. This high prevalence and incidence of UTI reported in this study may be attributed to the environmental conditions where the subjects reside. This may also be attributed to the lack of proper personal and environmental hygiene, genuine population susceptibility since these factors such as low socio-economic status, sexual intercourse, pregnancy among others are common among Nigerian men and women (Andriole, 1985; Akinyemi et al., 1997; Kolawole et al., 2009).

The low incidence rate of urinary tract infection reported among students $(30.4 \%)$ in this study may be attributed to the extensive health care talk given regularly in schools and public awareness programmes among the housewives. UTls were also more common among women whose husbands were transport workers, businessmen or in the armed forces. The incidence rate of bacteriuria among women in their first trimester is $42.5 \%$. This figure is higher than the prevalence rate of $2-9 \%$ reported by Nicolle (2003). This shows that symptomatic bacteriuria occurs in $17-20 \%$ of pregnancies. 
The findings of this study showed that $58.3 \%$ of the women who had UTIs were in their $3^{\text {rd }}$ pregnancy and above or have had more than 3 children; $43.7 \%$ were in their $2^{\text {nd }}$ pregnancy and $42.5 \%$ were in their $1^{\text {st }}$ pregnancy. This showed that parity is one of the possible factors affecting the incidence and prevalence rate of UTIs among women. This study also showed that women in their 6th month $(50.0 \%)$ and 7th month $(71.4 \%)$ of their pregnancy had the higher incidence of UTI while women in their early month of the pregnancy had no specific bacteria growth and shows no sign of UTIs.

In this study, women in their $2^{\text {nd }}$ and $3^{\text {rd }}$ trimester were found to have the higher incidence of UTI; $41.4 \%$ and $55.1 \%$ respectively. Though fewer women were in their first trimester, they showed no specific bacteria growth and show no sign of UTIs. Vazquez and Villar (2000) also reported that $10-30 \%$ of women with bacteriuria in the first trimester develop upper UTI in the second or third trimester. Thus, pregnant women should be screened for bacteriuria by urine culture at 12 to 16 weeks of gestation. The presence of $1 \times 10^{5}$ cfu of bacteria per $\mathrm{mL}$ of urine should be considered as highly significant.

Only fifteen samples were observed to have pus cells, 4 had Schistosoma haematobium and yeast cells. The pattern and frequency of occurrence of the bacterial isolates found in this study is similar what has been previously reported. E. coli is the most common pathogen among patients with uncomplicated UTIs (Kahlmeter, 2003). Other members of the family Enterobacteriaceae (such as some strains of Klebsiella spp.) and other organisms (such as Staphylococcus aureus), can have similar requirements (Barker et al., 1978; Tena et al., 2008).

The most implicating organisms causing urinary tract infections among these pregnant women in this study were Escherichia coli and were responsible for $42.1 \%$ of the cases of UTI. This was followed by S. aureus (28.9\%), $K$. aerogenes (18.4\%), P. aeruginosa (5.3\%) and mixed cultures of $K$. aerogenes and $S$. aureus (5.3\%). This finding is similar to other reports which suggest that Gramnegative bacteria, particularly $E$. coli is the commonest pathogen isolated in patients with UTI (Burbige et al., 1984; Akinyemi et al., 1987; Okonofua et al., 1989; Ebie et al., 2001; Njoku et al., 2001). Onifade et al. (2005) and Aiyegoro et al. (2007) also reported that E. coli was the most commonly isolated pathogen in significant bacteriuria. In a similar study by Nwanze et al. (2009) the commonest isolates were also Escherichia coli (51.2\%), S. aureus $(27.3 \%)$, and Klebsiella pneumoniae (12.8\%) respectively. This same pattern was also reported by Kolawole et al. (2009). However, the $18.4 \%$ incidence rate of $K$. aerogenes reported in this study brings to light the fact that Klebisella species are achieving more prominence as aetiological agents of UTI than previously reported (Obaseki, 1988; Abuidurahman et al., 1992; Adeyemo et al., 1994; Nwanze et al., 2009; Kolawole et al., 2009).

According to Murray et al. (1998), S. aureus is believed to cause cystis in mainly young sexually active females, this was also found to constitute a recognizable percentage in this study. This confirms that this organism may be achieving prominence as an aetiological agent of UTI in pregnant women. In this study, a total of 38 isolates were obtained from the 38 pregnant women with positive cultures; only one bacterial species was isolated from each subject, suggesting a mono-microbial nature of urinary tract infection in the study population. High incidence of UTI was found in age groups 36-40 years, though, a high percentage of the bacterial isolates were obtained mainly from pregnant women in age group 26-30 years. This confirms the usual report that the risk of UTIs increases with age. The pattern of isolates reported in this study is consistent with the usually reported pattern, with $E$. coli being the most common organism isolated in cases of urinary tract infection followed by $S$. auerus and $K$. pneumoniae. $P$. aerogunosa was the least common isolates in this study.

The high incidence of urinary tract infections reported among pregnant women might be as a result of a variety of factors; women under 50 years of age with acute symptoms such as dysuria, urgency or frequency suggesting of lower UTI or loin pain suggesting of upper UTI are extremely likely to have bacteriuria. Asymptomatic bacteriuria becomes increasingly common with age, though prevalence in men is always lower than for women of the same age. Alternations in vaginal microflora also play a critical role in encouraging vaginal colonization with coliforms and this can lead to urinary tract infection (Hooton et al., 1995). The prevalence rate of $1-3 \%$ asymptomatic bacteriuria was reported in Sweden from neonatal period to school age (Hooton and Stamm, 1997) while $5.3 \%$ prevalence was reported in Saudi Arabia (Omar and ElHaj, 1992). In Nigeria, a prevalence rate of $2.1 \%$ was reported in Enugu (Okafor et al., 1993);- in IleIfe, a prevalence rate of $24 \%$ and $6 \%$ was reported among rural and urban children respectively with an annual incidence rate of symptomatic bacteriuria of 6.5 per 1000 admissions (Aiyegoro et al., 2007), while Kolawole et al. (2009) reported $60 \%$ prevalence rate of UTI among patients attending Dalhatu Araf Specialist Hospital, Lafia, in Nasarawa State.

The high incidence rate of $47.5 \%$ reported in this study should be of great concern, as not only do UTIs pose a threat to health, but they also impose an economic and social burden due to the stigma associated with these infections. The findings of this study revealed that the important infecting organisms were found to be the commensals of perianal and vaginal regions. This calls for increase in personal hygiene (Kolawole et al., 2009). This study has highlighted the need to raise awareness of UTIs and to expand services for prevention and treatment for pregnant women. To do this effectively, however, it may be necessary to improve the quality of health care provided at the community level. Since UTI may be symptomatic and asymptomatic in most cases, it is therefore suggested that routine screening of patients with unexplained sources of fever be done for UTI and the appropriate antimicrobials administered after sensitivity tests have been carried out in order to prevent the cases becoming symptomatic later with resultant renal damage. 


\section{ACKNOWLEDGEMENT}

We wish to acknowledge the sincere contributions of the following people: Dr AO Okedare, for giving the expedited ethical approval for this study; Mr AO Adegoke and JO Ojo, for their assistance in the collection of this samples; the Nursing Sister-in-Charge of the Antenatal clinic; Dr AA Ogunjobi, for providing the computer used for browsing and searching of literature, typing the proposal and all other aspects of this work; Dr OD Adejoye, for technical contribution; Mr E Donbraye, for his moral support and assistance; Dr OG Oyero, for her immense assistance and guidance for this work and for providing the link to the hospital where this study was conducted.

\section{AUTHORS CONTRIBUTIONS}

IO Okonko conceived and designed the study, wrote the proposal for ethical approval, and principally financed the whole study, purchased the materials used for sample collection and laboratory analysis, he also assisted in collection of samples, the laboratory analysis and contributed principally in writing up the manuscript as well as the data and statistical analysis of this study. LA ljandipe addressed the subjects, also assisted in collection of samples, in the laboratory analysis and in reading of the results. OB Donbraye-Emmanuel provided the media for isolation and carried out the microscopy and the microbiological analysis of this study. AO llusanya supervised LA ljandipe who used part of the data for her B.Sc. Thesis in the Department of Microbiology, Olabisi Onabanjo University, Ago-Iwoye, Ogun state, Nigeria. AA Ogun, OA Akanbi, J Ejembi and TOC Faleye contributed equally in writing up this manuscript, editing, proof-reading and financing this publication.

\section{REFERENCES}

Abdulrahman, M. B., Amirlak, I. and Shamran, I. O. (1992). Urinary tract infection in children is still mismanagement problem. Emirates Medical Journal 10, 13-18.

Adeyemo, A. A., Gbadegesin, R. A., Onyemenen, I. N. and Ekweozor, C. C. (1994). Urinary tract pathogens and anti-microbial sensitivity in children in Ibadan, Nigeria. Annals of Tropical Paediatrics 14, 271-274.

Aiyegoro, O. A., Igbinosa, O. O., Ogunmwonyi, I. N., Odjadjare, E. E., Igbinosa, O. E. and Okoh, A. I. (2007). Incidence of urinary tract infections (UTI) among children and adolescents in Ile-Ife, Nigeria. African Journal of Microbiology Research 1, 13-19.

Akinkugbe, F. M., Familusi, F. B. and Akinkugbe, 0. (1973). Urinary tract infection in infancy and early childhood. East African Medical Journal 50, 514-520.

Akinyemi, K. O., Alabi, S. A., Taiwo, M. A. and Omonigbehin, E. A. (1997). Anti-microbial susceptibility pattern and plasmid profiles of pathogenic bacteria isolated from subjects with urinary tract infections in Lagos, Nigeria. Nigeria Quarterly Journal of Hospital Medicine 1, 7-11.
Alexander, D., Reith, B., Oureshi, S. and Twaddle, S. (2006). Management of suspected bacterial urinary tract infections in adults. A National Clinical Guideline, Scottish Intercollegiate Guidelines Network (SIGN). pp. 46.

American Academy of Family Physicians (AAFP) (2004). Urinary tract infections: A common problem for some women. Reviewed/Updated: 2008/04 Created: 2003/01. Available from http://www.aafp.org/afp/20050801/451.html

Andriole, V. T. (1985). The role of Tamm-Horsfall protein in the pathogenesis of reflux nephropathy and chronic pyelonephritis. Yale Journal of Biological Medicine 58, 91-100.

Anochie, I. C., Nkanginieme, K. E. O. and Eke, F. U. (2001). The influence of instruction about the method of urine collections and storage on the prevalence of urinary tract infection. Nigerian Journal of Paediatrics 28, 39-42.

Arthur, L. B., Smith, P. B. and Marvin, T. (1975). Clinical consideration: Laboratory diagnosis of urinary tract infection. USA 2, 1-4.

Asinobi, A. O., Fatunde, O. J., Brown, B. J., Osinusi, K. and Fasina, N. A. (2003). Urinary tract infection in febrile children with sickle cell anaemia in Ibadan, Nigeria. Annals of Tropical Paediatrics 23, 129-134.

Barker, J., Brookes, G. and Johnson, T. (1978). Carbon dioxide-dependent Klebsiellae. British Medical Journal 1 (6108), 300.

Buchanan, R. E. and Gribbons, N. E. (1974). Bergey's Manual of Determinative Bacteriology ( $8^{\text {th }}$ edition). Williams \& Wilkins Co. Baltimore USA.

Burbige, K. A., Retik, A. B., Colony, A., Bauer, S. B. and Lebowitz, R. (1984). Urinary tract infection in boys. Journal of Urology 132, 541-542.

Cheesbrough, M. (2002). Medical laboratories manual for tropical countries. Cambridge University Press. pp. 479.

Cheesebrough, M. (2004). District laboratory practice in tropical countries. Cambridge University Press. pp. 357.

Clarridge, J. E., Johnson, J. R. and Pezzlo, M. T. (1988). Laboratory diagnosis of urinary tract infections. Weissfeld A. S. (ed.). ASM Press, Cumitech 2B. Washington. pp. 2-19.

Duerden, B. I., Reid, T. M. S., Jewsbury, J. M. and Turk, D. C. (1990). A new shortbook of medical parasitic infection. ELBS Publishers. pp. 576-581.

Ebie, M. Y., Kandakai-Olukemi, Y. T., Ayanbadejo, J. and Tanyigna, K. B. (2001). Urinary tract infections in a Nigerian military hospital. Nigerian Journal of Microbiology 15, 31-37.

Ekweozor, C. C. and Onyemenen, T. N. (1996). Urinary tract infection in Ibadan; causative organism and antimicrobial sensitivity pattern. African Journal of Medical Science 25, 165-169.

Hooton, T. M. and Stamm, W. E. (1997). Diagnosis and treatment of uncomplicated urinary tract infection. Infectious Diseases \& Clinical Journal of North America 11, 551-581. 
Hooton, T. M., Winter, C., Tiu, F. and Stamm, W. E. (1995). Randomized comparative trial and cost analysis of 3-day antimicrobial regimens for treatment of acute cystitis in women. Journal of the American Medical Association 273, 41-45.

Ibeawuchi, R. and Mbata, T. I. (2002). Rational and irrational use of antibiotics. African Health 24, 16-18.

Jamieson, D. J., Theiler, R.N. and Rasmussen, S. A. (2006). Emerging infections and pregnancy. Emerging Infectious Diseases 12, 1638-1643.

Jellheden, B., Norrby, R. S. and Sandberg, T. (1996). Symptomatic urinary tract infection in women in primary health care. Bacteriological, clinical and diagnostic aspect in relation to host response to infection. (Comment). Scandinavian Journal of Primary Health Care 14, 122-128.

Kahlmeter, G. (2003). An international survey of the antimicrobial susceptibility of pathogens from uncomplicated urinary tract infection: the ECO. SENS Project. Journal of Antimicrobial Chemotherapy 51, 69-76.

Karen, C., Deron, C. H., Donal, H. V., Clenn, C. R., Lesile, T. H. and John, M. M. (1994). Laboratory evaluation of urinary tract infection in an ambulatory clinic. American Journal of Clinical Pathology 101, 100-103.

Karlowsky, J. A., Hoban, D. J., Decorby, M. R., Laing, N. M. and Zhanel, G. G. (2006). Fluoroquinoloneresistant urinary isolates of Escherichia coli from outpatients are frequently multi-drug: Results from the North American urinary tract infection collaborative alliance-quinolone resistance study. Antimicrobial Agents and Chemotherapy 50, 2251-2254.

Kolawole, A. S., Kolawole, O. M., Kandaki-Olukemi, Y. T., Babatunde, S. K., Durowade, K. A. and Kolawole, C. F. (2009). Prevalence of urinary tract infections (UTI) among patients attending Dalhatu Araf Specialist Hospital, Lafia, Nasarawa State, Nigeria. International Journal of Medicine and Medical Sciences 1, 163-167.

Kozliak, E. I., Fuchs, J. A., Guilloton, M. B. and Anderson, P. M. (1995). Role of bicarbonate $/ \mathrm{CO}_{2}$ in the inhibition of Escherichia coli growth by cyanate. Journal of Bacteriology 177, 3213-3219.

Kunin, C. M. (1994). Urinary tract infections in females. Clinical Journal of Infectious Diseases 18, 1-12.

Mbata, T. I. (2007). Prevalence and antibiogram of UTIs among prisons inmates in Nigeria. The Internet Journal of Microbiology 3 (2).

Morgan, M. G. and McKenzie, H. (1993). Controversies in the laboratory diagnosis of community acquired urinary tract infection. European Journal of Clinical Microbiology and Infectious Diseases 12, 491-504.

Murray, R. R., Rosenthal, K. S., Kobayashi, G. S. and Pfaller, M. A. (1998). Medical Microbiology. 3rd Edition Mosby Publishers. pp. 186.

National Institute for Health and Clinical Excellence (NIHCE) (2003). Antenatal Care: Routine Care for the Healthy Pregnant Women. London: NICE (Clinical Guidance 6). Available from
http://www.nice.org.uk/nicemedia/pdf/CG062NICEgui deline.pdf

National Kidney and Urologic Diseases Information Clearinghouse (NKUDFC) (2005). Fact sheet: Urinary Tract Infections in Adults. NIH Publication No. 06-2097.

National Institutes of Health (NIH) (2004). Fact Sheet: What I need to know about Urinary Tract Infections. NIH Publication No. 04-4807.

Nedolisa. (1998). Bacteriology of urinary tract infection amongst patients attending Jos University Teaching Hospital (JUTH). M.Sc. Thesis University of Jos, Nigeria. pp. 6-12.

Nicolle, L. E. (2003). Asymptomatic bacteriuria: When to screen and when to treat. Infectious Diseases \& Clinical Journal of North America 17, 367-394.

Njoku, C. O., Ezissi, N. H. and Amadi, A. N. (2001). Observations on bacterial infections of urinary tract patients. International Journal of Environmental Health and Human Development 2, 57-61.

Nwanze, P. I., Nwaru, L. M., Oranusi, S., Dimkpa, U., Okwu, M. U., Babatunde, B. B., Anake, T. A., Jatto, W. and Asagwara, C. E. (2007). Urinary tract infection in Okada village: Prevalence and antimicrobial susceptibility pattern. Scientific Research and Essay 2, 112-116.

Obaseki, E. (1988). Trimethoprin/sulphamethoxazole resistance in $E$. coli and Klebsiella sp. urinary isolates. African Medical Science Journal 17, 133140.

Ojiegbe, G. C. and Nworie, W. C. (2000). Asymtomatic bacteriuria among school pupils in Enugu Urban Areas. Journal of Medical Science 9, 42-46.

Okafor, H. V., Okoro, B. A. and Ibe, B. C. (1993). Prevalence of asymptomatic bacteriuria among nursery school children. Nigerian Journal of Paediatrics 20, 84-88.

Okonofua, E. E. A. and Okonofua, B. N. (1989). Incidence and pattern of asymptomatic bacteriuria of pregnancy in Nigerian women. Nigerian Medical Practitioner 17, 354-358.

Olaitan, J. O. (2006). Asymptomatic bacteriuria in female student population of a Nigerian University. The Internet Journal of Microbiology 2 (2).

Olowu, W. A. and Oyetunji, T. G. (2003). Nosocomial significant bacteriuria prevalence and pattern of bacterial pathogens among children hospitalized for non-infective urinary tract disorders. West Africa Journal of Medicine 22, 72-75.

Omar, E. E. and ElHaj, A. J. (1992). Urinary tract infections in school children in Saudi Arabia. Medical Digest 18, 3-7.

Onifade, A. K., Omoya, F. O. and Adegunloye, D. V. (2005). Incidence and control of urinary tract infections among pregnant women attending antenal clinics in government hospitals in Ondo State, Nigeria. Journal of Food, Agriculture and Environment 3, 37-38. 
Orenstein, R. and Wong, E. S. (1999). Urinary tract infections in adults. The American Academy of Family Physicians, March 2001.

Patton, J. P., Nash, D. B. and Abrutyn, E. (1991). Urinary tract infection: economic considerations. Medical and Clinical Journal of North America 75, 495-513.

Prescott, M., Harley, P. and Klein, A. (2008). Microbiology $7^{\text {th }}$ edition. McGraw-Hill: New York. pp. 124-126.

Smith, P. J., Morris, A. J. and Reller, L. B. (2003). Predicting urine culture results by dipstick testing and phase contrast microscopy. Pathology 35, 161-165.

Solberg, O. O., Ajiboye, R. and Riley, L. W. (2006). Origin of class 1 and 2 integron and gene cassettes in a population-based sample of uropathogenic Escherichia coli. Journal of Clinical Microbiology 44, 1347-1351.

Stamm, W. E. (2002). Scientific and clinical challenges in the management of urinary tract infections. The American Journal of Medicine 113, (supplement 1): 1-4.

Tapsal, J. W., Bell, S. M., Taylor, P. C. and Smith, D. D. (1975). Relevance of significant bacteriuria to aetiology and diagnosis of urinary tract infection. Lancet 11, 637-639.

Tena, D., González-Praetorius, A., Sáez-Nieto, J. A. Valdezate, S. and Bisquert, J. Urinary tract infection caused by capnophilic Escherichia coli [letter]. Emerg Infect Dis [serial on the Internet]. 2008 July [cited 2009 June, 30]. Available from http://www.cdc.gov/EID/content/14/7/1163.htm. DOI: 10.3201/eid1407.071053

Vazquez, J. C. and Villar, J. (2000). Treatment for symptomatic urinary tract infections during pregnancy (Cochrane Review). In: Cochrane Library. Issue 3. John Wiley and Sons Ltd., Chichester, UK.

Weinstein, M. P., Towns, M. L. and Quartey, S. M. (1997). The clinical significance of blood cultures in the 1990s: A prospective comprehensive evaluation of the microbiology, epidemiology and outcome of bacteraemia and fungemia in adults. Clinical Infectious Diseases 24, 584-602. 